\title{
Exploring alternative approaches to entrepreneurial exporting: internationalization through an effectual lens
}

Norah R. Cussen

Technological University Dublin, norah.cussen@tudublin.ie

Thomas M. Cooney

Technological University Dublin, thomas.cooney@tudublin.ie

Follow this and additional works at: https://arrow.tudublin.ie/creaart

Part of the Business Commons

\section{Recommended Citation}

To cite this article: Norah Cussen \& Thomas Cooney (2019) Exploring alternative approaches to entrepreneurial exporting: internationalization through an effectual lens, Small Enterprise Research, 26:2, 164-178, DOI: 10.1080/13215906.2019.1624603 To link to this article: https://doi.org/10.1080/ 13215906.2019 .1624603

This Article is brought to you for free and open access by ARROW@TU Dublin. It has been accepted for inclusion in Articles by an authorized administrator of ARROW@TU Dublin. For more information, please contact arrow.admin@tudublin.ie, aisling.coyne@tudublin.ie, gerard.connolly@tudublin.ie.

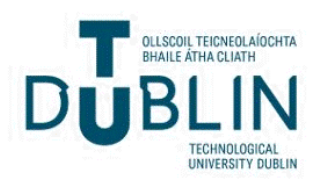




\section{Small Enterprise Research}

\section{Exploring alternative approaches to entrepreneurial exporting: internationalization through an effectual lens}

\section{Norah Cussen \& Thomas Cooney}

To cite this article: Norah Cussen \& Thomas Cooney (2019) Exploring alternative approaches to entrepreneurial exporting: internationalization through an effectual lens, Small Enterprise Research, 26:2, 164-178, DOI: 10.1080/13215906.2019.1624603

To link to this article: https://doi.org/10.1080/13215906.2019.1624603

\section{曲 Published online: 11 Jun 2019.}

Submit your article to this journal ๘

Џlll Article views: 165

Q View related articles $\longleftarrow$

View Crossmark data ¿ 


\title{
Exploring alternative approaches to entrepreneurial exporting: internationalization through an effectual lens
}

\author{
Norah Cussen and Thomas Cooney \\ College of Business, School of Marketing, Technological University Dublin, Dublin, Ireland
}

\begin{abstract}
In 2017 EU exports supported 36 million jobs in the EU. Furthermore, it was estimated that on average each billion euro of extra-EU exports supported more than 13,000 jobs in the EU Exporting is widely viewed as one of the key drivers of economic growth and many traditional approaches have been applied to engender greater levels of exporting by indigenous enterprises. However, Sarasvathy [(2001). Causation and effectuation: Toward a theoretical shift from economic inevitability to entrepreneurial contingency. Academy of Management Review, 26, 243-263, (2013). An effectual approach to international entrepreneurship: Overlaps, challenges and provocative possibilities. The Journal of Entrepreneurship Theory and Practice, 71-95] on 'Effectuation' suggests that an alternative approach to achieving entrepreneurial growth might be possible. This article seeks to address a gap in existing literature regarding the relationship between exporting and effectuation.
\end{abstract}

\section{KEYWORDS}

Entrepreneurship; exporting; effectuation; government intervention; policy; economic growth

\section{Introduction}

In recent times, successive European Union reports have highlighted the importance of entrepreneurship for job creation and the development of a sustainable national economy. The EU is the world's largest exporter of manufactured goods and the EU economy is already one of the most open regions for economic trade (European Commission, 2019). Within the EU, Ireland is a small island economy that operates within and contributes to the wider EU. Ireland's small domestic and open market has resulted in many enterprises turning to exporting to grow their business. According to the CSO (2019), the value of goods exported for February 2019 was $€ 12,614$ million representing an increase of $€ 2212$ million (+21\%) when compared with February 2018. The value of goods exported for the period January and February 2019 was $€ 26,313$ million, an increase of $€ 3808$ million (+17\%) when compared with the first two months of 2018 . The EU accounted for $€ 6101$ million (48\%) of total goods exported in February 2019, of which $€ 1626$ million went to Belgium and $€ 939$ million went to Germany. Total EU exports in February increased by $€ 676$ million (+12\%) compared with February 2018. The USA was the main non-EU destination accounting for $€ 3720$ million (29\%) of total exports in February 2019. The decision to export is based on a variety of factors that influence 
owner-managers of Small Medium Enterprises (SMEs) in determining their path to internationalization. A CSO (2016) study of exporting by enterprise size found that there were 7900 SMEs exporting goods in 2016 and the total value of their exports was $€ 36.4$ billion, or $31 \%$ of total exports. This figure included 5007 micro enterprises, which exported $€ 6.9$ billion of goods. However, in 2017, €192.5 billion of exports was generated by foreignowned companies and just $€ 21.3$ billion exports was from Irish-owned companies (equivalent of $9.96 \%$ of total exports). This suggests that Irish-owned firms are performing poorly in comparison to foreign-owned firms and that SMEs are performing poorly in comparison to large enterprises. The constant challenge for Irish governments has been to encourage a greater number of Irish-owned SMEs to engage in international trade and many incentives have been established to support such activity. However, as Crick and Crick (2016) highlighted, decisions to internationalize are frequently made in the context of perceived risk/reward considerations regarding exploiting various opportunities. This article examines if the concept of effectuation could be utilized as an alternative approach to improving entrepreneurial exporting activity in Ireland.

\section{Effectuation}

Entrepreneurship is a complex and dynamic activity which has been studied from many different perspectives across the years (Casson \& Wadeson, 2007). The traditional approach is causal reasoning, whereby entrepreneurs will determine their goals and then look for the resources to achieve them. The opposite is true of effectuation (Sarasvathy, 2001), whereby entrepreneurs will determine goals according to the resources already available to them. Effectuation does not require end goals or a resource-constrained environment and can be applied by any individual seeking to express enterprising behaviour. Effectuation is centred on the individual entrepreneur and their ability to utilize the means available to them. Sarasvathy (2012) suggested that what makes entrepreneurs entrepreneurial is their different reasoning process, called effectual reasoning. Instead of having a predetermined goal to begin the process of opportunity identification and new venture creation, an entrepreneur will use the means available to them to proceed. Using Sarasvathy's (2001) concept, it can be suggested that entrepreneurs use the skills or means available to them, whether the traits suggested by $\mathrm{Wu}$ and $\mathrm{Li}$ (2011) or their skills such as education (Delmar \& Davidsson, 2000), and this is what makes them entrepreneurial.

Managerial logic has a predetermined goal and people who employ this approach use the means provided to them by senior management to achieve their given goals. Similarly, strategic thinkers have a predetermined goal and will generate the means to achieve this goal. However, entrepreneurs who apply effectual logic do not have a predetermined goal and simply utilize the means available to them to produce an outcome. Effectual logic suggests that an entrepreneur uses the resources available to overcome barriers (such as those suggested by Bobera, Lekovic, \& Berber, 2014) to progress their entrepreneurial journey (Individual Opportunity Nexus) and this approach may have significant implications for SMEs seeking to become active in exporting. Effectual logic suggests that it is an entrepreneur's ability to use the means available to become successful that differentiates them from non-entrepreneurs. It could also be advocated that such entrepreneurs use the characteristics they possess (or the means their circumstances provide) and 
naturally this would differ with every individual and no longer provide a distinct entrepreneurial character. It also separates entrepreneurs from non-entrepreneurs in the sense that they each apply a different type of logic.

Globalization is changing the business environment and markets are becoming more open. This has resulted in businesses having to become more entrepreneurial to enable them to adapt to change. This is also affecting the creation of firms and how businesses processes are viewed. Sarasvathy (2001) argued that in an ideal world, an individual would know exactly the type of firm or business venture they wanted to create and could decide which strategy would best fit their business objectives. However, this is not the case for an entrepreneur since an entrepreneur sets out with a vague idea of what they are trying to achieve and will make decisions and estimations about what is not yet in existence. Sarasvathy (2001) suggested that the theory of effectuation could provide an explanation for this process. This perspective is reflected in Kim and Mauborgne (2005) with the comparison of Blue and Red Oceans. Blue Ocean Thinking means exploring known market spaces akin to the logic of effectuation. Sarasvathy (2001) did not suggest that an entrepreneur should disregard causal thinking, rather they should practice both causal and effectual logic depending on their circumstances and advocated that the best entrepreneurs will be able to implement both effectively. Furthermore, Sarasvathy (2001) stated the evidence suggested that as an entrepreneurial company grows to exceed a critical size, effectual reasoning should be supplemented with causal modes of thinking.

It is evident that Effectuation Theory has recombined existing entrepreneurial research to produce a new perspective to entrepreneurship. Read, Song, and Smit (2009) furthered the study of effectuation and conducted a meta-analysis of 48 studies of 9897 new ventures and connected three of the principles of effectuation positively with new venture performance - Means, Partnerships and Leveraging Contingencies. A longitudinal study of 736 nascent entrepreneurs by Mauer et al. (2010) sought to understand the dynamics between the key principles of effectuation and the process of the start-ups. Two of the four principles explored (means orientation and partnerships) had a direct effect, whereas affordable loss and leveraging contingencies are indirect. Kraaijenbrink et al. (2010) analysed the business plans of 92 firms and found that larger businesses tend to practice both means and end goal orientation, whereas smaller businesses focus on means. Anderson (2011) conducted a longitudinal case study and found effectuation was present in the early development of a born global business. Further empirical studies have also produced positive findings (Brettel, Mauer, Engelen, \& Küpper, 2012; Perry, Chandler, \& Markova, 2011; Chesbrough, 2010; Chiles, Bluedorn, \& Gupta, 2007; Reymen, Berends, Oudehand, \& Stultiens, 2016) highlighting that effectual logic is present in multiple contexts, with a specific emphasis on means orientation (bird in the hand). Previous studies have been conducted to explore effectuation in the entrepreneurial process (Galkina, 2013) and found that entrepreneurs use effectual logic to build international networks, but none have examined this solely from the perspective of entrepreneurial exporting activity. Evers and O'Gorman (2011) also found that entrepreneurs apply Effectual logic when they identify international opportunities. They utilize existing resources (means) to identify and select international opportunities through factors such as an entrepreneur's knowledge of international markets and their social network (which enabled them to build networks and partnerships). 


\section{Exporting}

Many entrepreneurs and SMEs choose exporting as an entry mode when accessing new markets as it does not require any foreign investment of assets because it is located and controlled domestically. This is suitable as many firms start the internationalization process when they are relatively small and such an approach allows them to gradually develop their international operations (Rasheed, 2005). Johanson and WiedersheimPaul (1975) suggested that exporting happens in stages and that this staged approach reduces risks and barriers associated with exporting. This staged approach involves four steps which are: no regular export activities; exporting via independent representative or agent; sales subsidiary; production / manufacturing. Freund and Pierola (2001) examined entrepreneurs exporting and rather than a staged entry mode, they suggested that entrepreneurs should begin exporting using a trial-and-error model by testing small amounts of export products in new markets as a means of reducing entry costs and failure rate. This allows entrepreneurs to test the new product/market without experiencing large investments or losses. There are many reasons entrepreneurs turn to exporting, some by choice and others by necessity, with Putninšs (2013) identifying a small domestic market as a driver for businesses to turn to exporting to grow their business. That said, businesses from larger domestic markets also view exporting as a means of expansion and market entry. Putniņš (2013) studied Lativan-based exporting companies and found that they tended to be larger, younger and faster growing than non-exporting companies. Businesses that engage in exporting have also been found to be more innovative, productive and risk taking, and therefore have a higher entrepreneurial orientation, characteristics akin to those of a successful entrepreneur ( $\mathrm{Wu} \& \mathrm{Li}, 2011$ ).

It has been suggested that the main issues for exporters and entrepreneurs alike are financial burdens (Putniņš, 2013). However, Greenaway, Guariglia, and Kneller (2007) found that exporters exhibit better financial health than non-exporters and that participating in export markets will improve the financial health of a struggling businesses. Greenaway et al. (2007) also suggested that the growth in financial health decreases as exporting activities continue. Although this view is not reflected by Albornoz, Calvo Pardo, Corcos, and Ornelas (2012) and Klein, Moser, and Urban (2013) who found that exporters see increased profitability the more they continue engaging in export activity. A study of UK-based companies found that an ever-increasing number of companies are exporting, with more than two-thirds of companies surveyed engaging in exporting activity. This study also found that companies who export tend to be larger and more profitable. Its findings also revealed that new exporters find a surge in productivity in the year they first enter a new market (Greenaway \& Kneller, 2007). Van Biesebroeck (2005) studied manufacturing firms and found that exporting increases productivity and allows them to achieve economy of scale. The findings of Putninšs (2013), Greenaway and Kneller (2007) and Van Biesebroeck (2005) all support the notion that successful exporting can grow or revive a business's productivity. Similar benefits of exporting were also found by Albornoz et al. (2012), but their study also found that many exporters cease exporting shortly after starting due to financial constraints. Meanwhile, Anderson and Van Wincoop (2004), Putniņš (2013) and Greenaway and Kneller (2007) agreed that the main reason many firms do not export (or cease exporting) is due to trade costs. However, those that do not give up see increased sales and profitably, plus continue to expand to new 
destinations. This allows exporters to overcome the initial uncertainly that is associated with first-time exporters and recover any initial financial losses, making continued exporting highly worthwhile (Albornoz et al., 2012).

Putniņš (2013) identified legal barriers in foreign markets as another major issue, along with a lack of knowledge about the foreign market and exporting process. These barriers are increased by cultural differences and language constraints. Sarasvathy et al. (2013) found that these barriers are harder to overcome due to exporters cross-border uncertainty and limited resources. Exporters also find strong competition an issue in foreign markets and struggle to compete with price and building a brand reputation. These barriers are in turn affected by network barriers, as exporter's struggle to build and maintain international networks, which have been found to reduce barriers (Johanson \& Wiedersheim-Paul, 1975; Putniņš, 2013; Sarasvathy et al., 2013). Research by Klein et al. (2013) supports the findings that engaging in export activity will increase a firm's demand levels and increase productivity but discovered that this requires the firm to hire a more skilled workforce. However, availability of skilled workforce also has been found to be a major issue for exporters (Putniņš, 2013). Grandinetti and Mason (2012) examined the determinants of export performance and highlighted that firms exporting rather than investing directly in foreign marketing can result in a lack of knowledge about the new market. Firms that do invest directly have the benefit of being able to gain local knowledge and information that enable them to adopt marketing strategies to the specific characteristics of that market. This also allows them to adapt quickly to market changes that may not be seen through exporting and build a reputation in the new market with a physical presence. Lack of knowledge of new market and culture also leads to cross-border uncertainty (Putniņš, 2013; Sarasvathy et al., 2013) which causes firms to only export to neighbouring countries with similar business practices (Johanson \& Wiedersheim-Paul, 1975). However, there is an increased risk with smaller scope of destinations. Putniņš (2013) found in order to overcome these barriers, exporting companies needed to take actions such as long-term strategy planning, preparation, partnership and regular visits to export markets. However, it is not always feasible for start-ups to carry out these actions, especially establishing partnerships and undertaking regular visits to export markets (Grandinetti \& Mason, 2012). Nguyen (2012) examined the reasons why exporters failed and akin to Putninšs (2013) found issues such as poor planning, wrong timing and product failure, as being critical. Nguyen (2012) studied these issues and presented a model as an attempt to reduce failure rate. However, this model only presented a solution for pre-existing exporting firms as first-time exporters do not have the required knowledge.

It is widely acknowledged that exporting increases productivity (Albornoz et al., 2012; Greenaway et al., 2007; Greenaway \& Kneller, 2007; Klein et al., 2013; Putniņš, 2013; Van Biesebroeck, 2005). Crespi, Criscuolo, and Haskel (2008) examined how firms increase productivity when continuing to export and found that exporters learn from previous clients and use this to continue exporting activity. This study found that UK firms did not cite other sources as a knowledge resource for exporting activity (such as government support agencies), but instead used their experience with clients and customers to increase their growth (using available resources). If such is true, it presents a problem for first-time exporters who do not have the facility of learning from previous clients. Nguyen's (2012) model for forecasting exporting demand presented the same problem, as start-ups or first- 
time exporters do not have pre-existing knowledge or experience. Overall, it is evident that first-time exporters face a vast array of barriers, which differ depending on the business being conducted. Therefore, alternative approaches regarding how these exporters deal with the barriers need to be explored. The literature on entrepreneurship and exporting are interlinked as many of the struggles of the entrepreneur are similar for first-time exporters, such as finance and costs (Anderson \& Van Wincoop 2004; Greenaway \& Kneller, 2007; Putninšs, 2013). The literature also suggested that while firms have initial barriers with exporting activity, long-term it will increase their productivity and financial health (Greenaway \& Kneller, 2007; Putniņš, 2013; Van Biesebroeck, 2005). The literature on government interventions suggests that while government may succeed in addressing certain economic and market issues, their interventions can also have little impact if not utilized by owner-managers and this must also be considered (Aikins, 2009; Young, Butler, Jordan, \& Watt, 2012).

\section{Methodology}

The philosophical approach adopted for the study was epistemology as this is concerned with what constitutes acceptable knowledge in a field of study, how do we know, what we know? (Saunders, Lewis, \& Thornhill, 2012). Steup (2014) defined epistemology in the Stanford Encyclopedia of Philosophy as the study of knowledge and justified belief. The term epistemology is commonly described as being concerned with the creation and dissemination of knowledge in specific areas of inquiry. An approach to epistemology is interpretivism as this approach supports the importance of understanding humans and their interactions with each other, as well the affects these have on society. Interpretivism recognizes the difference between researching objects and people. This approach suggests that humans play specific roles in society, but how one interprets these roles is in accordance with the meaning one places on them. An interpretivist perspective is appropriate for business research as it allows the researcher to enter the participant's social world and understand their view point. The focus in this approach is on the details of the situation, the reality behind these details and the subjective meaning which motivates the actions (Saunders et al., 2012). This study focused on the details of an entrepreneur's decisionmaking process when engaging in exporting activity. An inductive approach was employed as known premises were being used to generate untested results, meaning that effectuation and government intervention were being explored to examine their relationship to entrepreneurial exporting activity. The data collected was used to explore a phenomenon which identified themes for analysis and was the basis for building on existing theory (Saunders et al., 2012).

Given the nature of this research, it was decided that a qualitative approach would be best suited. Perry et al. (2011) review of Sarasvathy's Entrepreneurial Effectuation, concluded that based on the existing literature the study of Effectuation is at a nascent/intermediate stage and more research was needed to be conducted in this area. Also, little is known about the possibility of Effectuation as an alternative approach to meeting policy objectives. The methodology involved five semi-structured interviews which produced a large quantity of rich text data from the interviewees. The time horizon was cross-sectional as the data from the interviews was being collected just once. This was considered appropriate for this study as the data required could be taken from the 
interviewees' past and current experiences (Sekaran \& Bougie, 2010). Semi-structured interviews allowed the interviewers to have a list of topics to be covered and possibly some key questions, although their use varied with each interview. This allowed the interviewers to adapt the interview structure as needed. The order of the questions also varied depending on the flow of the questions as each interviewee differed in response. The data for these types of interviews was captured using audio-recording and note-taking (Saunders et al., 2012). Saunders et al. (2012) found that managers are more likely to agree to interviews when the topic is seen to be interesting to their current work. The interview provides them with a chance to voice their opinions without having to write anything down. The interviews varied in structure and length as the participants come from a variety of industries with very different experience and views on the topic. As Thematic Analysis was used, key topics and research objectives were identified from the literature, so that the data collected could be used to find common themes.

For this research, non-probability sampling was used as this is an exploratory study and it was focusing on a small number of samples, which had been selected for a particular purpose (Saunders et al., 2012). When using non-probability sampling and semi-structured interviews, it is suggested that at least 5 samples are required. The technique used is theoretical sampling, as the sample selection was chosen based on developing categories and emerging theory based upon simultaneous collection, coding and analysis of data. The researchers selected potential interviewees deemed most suitable to provide an insight into the topic being explored. It was decided that the participants should be entrepreneurs engaging in exporting activity from a variety of industries. A traditional access approach was utilized, and the interviewees were contacted via phone and email, and informed prior to the interview of the nature and propose of the research. They were also informed of their contribution to the research and how it would benefit the study which helped to build a relationship between the interviewer and interviewee. However, it was difficult to gain support for the study as many potential interviewees did not respond or were not interested in participating. After the initial contact with participants that agreed to be interviewed, the face-to-face interviews were scheduled. The access that was granted by the participants was cognitive access which infers that the interviewee is allowing the researcher access to the data that is required to answer the primary research question. The participants were found through internet searches, existing contacts and Enterprise Ireland. The researchers ultimately succeeded in interviewing entrepreneurs for the purposes of the study (detailed in Table 1).

The participants detailed in Table 1 were all engaged in exporting and were from various industries in Ireland. Two of the five participants had availed of government support which allow for a comparison of perspectives.

\section{Discussion}

Each interview was individually analysed and cross-analysed. The first interview was analysed in detail for possible key themes and these were discussed at the following interviews. The method used to analyse the data was thematic analysis. This involved initial coding, which identified recurring key words and allowed the researcher to identify the themes and sub-themes presenting. A theme captures something important about the data in relation to the research question and represents some level of patterned response or 
Table 1. Detail of interview participants.

\begin{tabular}{|c|c|c|c|}
\hline Interviewee & Role within the company & Experience with government support & Industry \\
\hline Interviewee 1 & Founding Director & No support received & Telecommunications \\
\hline Interviewee 2 & Owner & No support received & $\begin{array}{l}\text { Co-working offices for } \\
\text { entrepreneurs and IT consultant }\end{array}$ \\
\hline Interviewee 3 & Founding Director & Received government support & Retail technology \\
\hline Interviewee 4 & Founding Director & Received government support & Retail technology \\
\hline Interview 5 & Owner & No government support received & Fishing \\
\hline
\end{tabular}

meaning within the data set (Braun \& Clarke, 2006). The next step is focused coding which involves reanalysing the data to ensure the validity of the codes and that they were free of bias, so the data was re-read and checked multiple times. An inductive approach was used in the analyses, as Yin (2009) stated the importance of examining the data as the research progresses to identify emerging themes. The software tool used to analyse the data was Nvivo (Table 2).

Nvivo is a qualitative analysis computer software package which is used for rich textbased data. The interviews were audio recorded and carefully transcribed to report what was stated by the interviewees and notes were made to describe how they said it (e.g. tone that was used). Each interview was transcribed within hours of it being recorded. Thematic analysis comprised of grounded theory, positivism, interpretivism and phenomenology, all synthesized into one methodological framework. Thematic analysis allows a researcher to examine themes from textual data in a way that is transparent and credible (Braun and Clarke, 2006; Quest, McQueen, \& Namey, 2012). The themes must then be reviewed so that they are coherent, consistent and distinctive. From this a report for discussion can then be produced. The following themes were derived from the analysis in order to explore the given research problem.

\section{Theme 1: To explore the factors which enable entrepreneurs to export - push or pull factors}

This theme explored the situation that led an entrepreneur to exporting and if the entrepreneur had a predetermined goal to export or if they were led by opportunity (Bobera et al., 2014; Carland, Hoy, \& Carland, 1988; Castaño, Méndez, \& Galindo, 2015; Renko, 2012; Shane \& Venkataraman, 2000). This theme explored the factors which enable entrepreneurs to export. There were several sub-themes that emerged from the respondents (Table 3).

The data suggested that majority of reasons offered by entrepreneurs for engaging in exporting could be described as pull factors as they were based on opportunities that emerged from connections or business prospects. The interviewees referenced identifying

Table 2. Coding and analysis in NVivo.

\begin{tabular}{|c|c|}
\hline Step 1 - Develop Initial Nodes & $\begin{array}{l}\text { Open coding was applied and nodes where named based on emergent } \\
\text { themes }\end{array}$ \\
\hline Step 2 - Develop Relationships & Nodes were the groups formed together to represent collective themes \\
\hline Step 3 - Second Analysis of the Data & $\begin{array}{l}\text { The data was reanalysed with the nodes constructed from literature to } \\
\text { explore reference to Effectuation theory }\end{array}$ \\
\hline Step 4 - Third Analysis within Theme & $\begin{array}{l}\text { The data was then reanalysed from a theme perspective and nodes were } \\
\text { individually analysed to identify further emergent themes }\end{array}$ \\
\hline Step 5 - Comparison with the Literature & The themes were then compared with the agreeing and conflicting literature \\
\hline $\begin{array}{l}\text { Step } 6 \text { - Formation of the Conclusion and } \\
\text { Recommendation }\end{array}$ & $\begin{array}{l}\text { The Conclusion and recommendations were formed based on the emergent } \\
\text { themes }\end{array}$ \\
\hline
\end{tabular}


Table 3. Theme 1 coding.

\begin{tabular}{lcl}
\hline Node name & References & \multicolumn{1}{c}{ Description } \\
\hline Pull factor & 17 & Reference to opportunity to export \\
Push & 4 & Reference to export as necessity \\
\hline
\end{tabular}

opportunities and prospects being presented to them in their direct conversation. While there were only 4 references to push factors, it was frequently evident that this was a major theme. An example of this in illustrated in Interviewee 1's discussion of push and pull factors.

- Pull factor: The first reason, obviously we are on the island of Ireland and we were initially operating in the 26 counties and the counties in Northern Ireland represented an opportunity to increase our market and grow our business. We had the rights from our suppliers to sell into that jurisdiction, so we endeavoured to tender for hospital projects in the north of Ireland. We were successful with our first one, which led to us selling excess of $€ 300,000$ worth of equipment and subsequently providing maintenance contracts for years after that.

- Push factor: 'Well I knew that to grow the business in Northern Ireland given the nature of the economy, we would need a company in Northern Ireland.'

This would suggest that while entrepreneurs pursued opportunities to export (pull factors), this internationalization was a result of necessity for growth, to remain competitive or an impact of economic conditions (push factor). The interviewees further validated this with the challenges they faced with exporting or deciding to export. This led into the second theme, the need for government support. This theme further suggests that exporting entrepreneurs apply a means-based approach when deciding to export, suggesting they look at what they can do (internal) and need to do (external) based on their current means and environment. This would postulate a relationship between commencing exporting and Effeuctation's 'Bird in the Hand' principle (Sarasvathy, 2001).

\section{Theme 2: To explore an entrepreneur's knowledge, experience and perceptions of entrepreneurship policy in reducing barriers to entrepreneurial export activity}

This theme is focused on establishing an entrepreneur's awareness of government supports, the effectiveness of these supports and if the government imposed any barriers on the entrepreneurial exporting process (Action Plan for Jobs, 2015; Central Bank of Ireland, 2015; Department of Enterprise, Trade \& Innovation, 2015; Irish Exporters Association, 2014). The goal of this theme was to explore the extent that entrepreneurs are aided by government interventions, as well as their knowledge and perceptions of government interventions.

Table 4 presents the overall reference to different criteria when discussing government support for exporting. There were 14 references to awareness of government support and the discussion suggests that entrepreneurs knew there was funding available, but they did not feel they met the relevant criteria (this was primarily due to the reference about needing to be a high potential growth firm). There was a low level of disparity between 
Table 4. Theme 2 coding.

\begin{tabular}{lrl}
\hline Node name & References & \multicolumn{1}{c}{ Description } \\
\hline Awareness of government supports & 14 & $\begin{array}{l}\text { Reference to a knowledge of supports available for exporting } \\
\text { Lack of awareness }\end{array}$ \\
$\begin{array}{l}\text { Negative perceptions of government } \\
\text { support }\end{array}$ & 20 & $\begin{array}{l}\text { Partipants were not aware of an available support } \\
\text { Refence to a negative perception of government role in } \\
\text { supporting entrepreneurs }\end{array}$ \\
$\begin{array}{l}\text { Positive perceptions of government } \\
\text { support }\end{array}$ & 18 & $\begin{array}{l}\text { Reference to a positive perception of government role in supporting } \\
\text { entrepreneurs }\end{array}$ \\
$\begin{array}{l}\text { Need for support } \\
\text { Availed of government support }\end{array}$ & 23 & $\begin{array}{l}\text { Reference so a self-identified need for support } \\
\text { Reference to receiving support from government }\end{array}$ \\
\hline
\end{tabular}

the number of references regarding positive and negative perceptions of government support; while participant had negative perspectives of supports in terms of finance, they had positive perspective of governments broader role in supporting entrepreneurs in Ireland. However, there was a strong reference for a need for support regarding mentoring and sales training for exporting business. This aligns with the Effectual Cycle which suggests that export entrepreneurs create commitments from interactions that allow them to co-create and achieve goals. This led to a negative perception of government supports, with 20 references to this. While there were 18 references to positive perceptions, these were predominantly from the two interviewees who had availed of government supports from Enterprise Ireland. Interviewee 3 suggested that without Enterprise Ireland they would not have achieved their goals. The strong positive perception of the support they received is highlighted in the statement:

Yes hugely, we would not be here were it not for Enterprise Ireland. We found them incredibly professional to deal with.

While other interviewees may not have expressed a positive perception, they were aware that government cannot 'fund' all entrepreneurial activity. This led to discussions concerning the role government should play in supporting exporting with the main suggestion being mentoring which would enable entrepreneurs to gain knowledge about selecting international markets and exporting. The suggestion also emerged that this should be provided by experienced international business professionals rather than civil servants/enterprise agency personnel. There was also the perception that government support is focused on those already exporting and not those wishing to pursue exporting opportunities. The interviewee highlights this in the statement:

I was generally aware that there was help, but this help is for exporting company. Because of being so busy business with our internal business and because we were starting on small scale we were much more inclined to do it ourselves and because we had the resources and experience.

Interviewee 1's statement suggests perceptions of government, but also a strong reference to means-based processes which were explored in Theme 3.

\section{Theme 3: To explore the concept of effectuation for entrepreneurial exporting activity}

This theme explored whether the concept of Effectuation can be extended to exporting activity, and if the participants applied effectual logic (Sarasvathy, 2012) and the principles 
of Effectuation (Sarasvathy, 2001). The purpose of this theme was to explore the possibility of effectuation as a 'grassroots' level mechanism to contribute to exporting growth. Table 5 presents the reference to the principles of Effectuation theory throughout the discussions with the interviewees. These references were made in terms of their entrepreneurial journey that led them to exporting. The node means-based process (Bird in the Hand) presented 25 references throughout the data suggesting that exporting entrepreneurs used the means and opportunities available to achieve entrepreneurial growth through exporting. Theme 1 explored the push and pull factors that led entrepreneurs to pursue entrepreneurial growth and combining these emerging themes it would suggest that entrepreneurs apply a means-based approach when pursuing exporting. The theme of means-based processes also correlated with lemonade themes (leveraging events) which is deemed to be associated with the resource-constrained environments that led the entrepreneurs to pursue export opportunity (e.g. economic conditions/small island economy). This suggests that Effectuation principles Bird in Hand and Lemonade directly link to the push factors analysed in Theme 1. Regarding the principle Affordable Loss in the context of exporting, entrepreneurs started small pursuing opportunities that the business could sustain.

Patchwork Quilt was not identified as a major factor in the export process as only entrepreneurs who engaged in funding from government directly referenced this. The low representation of Patchwork Quilt correlates with the strong reference to a need for support or networks which was identified in Theme 2. This suggests that as means to improve the entrepreneurial exporting process entrepreneurs would benefit from networking opportunities to create a Patchwork Quilt of partnership and opportunities to leverage resources. Interview 2 stressed how important this is to entrepreneurs and that they need to be able to build networks and make sales. Interview 2 compared new international markets with a new entrepreneur trying to setup in Ireland in the following statement:

There is differences between the way entrepreneurs sell and the way they are thought to sell. An experienced sales person has a different experience selling, you have to walk in and sell and convince people when you've only been around six months and that you'll be here in six months. There is a difference to selling as an entrepreneur and start-up.

This suggested that sales training and building networks are fundamentals for building reputations in new markets.

Throughout the data there were also references to focusing on what can be controlled in the exporting process rather than estimating risk (Pilot in the Plane). The theme emerging throughout this node suggested that entrepreneurs focus on controllable events to drive

Table 5. Theme 3 coding.

\begin{tabular}{lcl}
\hline Node name & References & \multicolumn{1}{c}{ Description } \\
\hline $\begin{array}{l}\text { Means-based } \\
\text { processes }\end{array}$ & 25 & Processes that focus on selecting means for exporting \\
$\begin{array}{l}\text { Affordable loss } \\
\text { Lemonade }\end{array}$ & 16 & $\begin{array}{l}\text { Reference to assessing what I can afford to lose in the exporting process } \\
\text { Reference to an entrepreneur using exporting as a point of leverage (linked to node } \\
\text { on push factors) }\end{array}$ \\
$\begin{array}{l}\text { Patchwork quilt } \\
\text { Reference to partnerships to overcome barriers to exporting }\end{array}$ \\
\hline
\end{tabular}




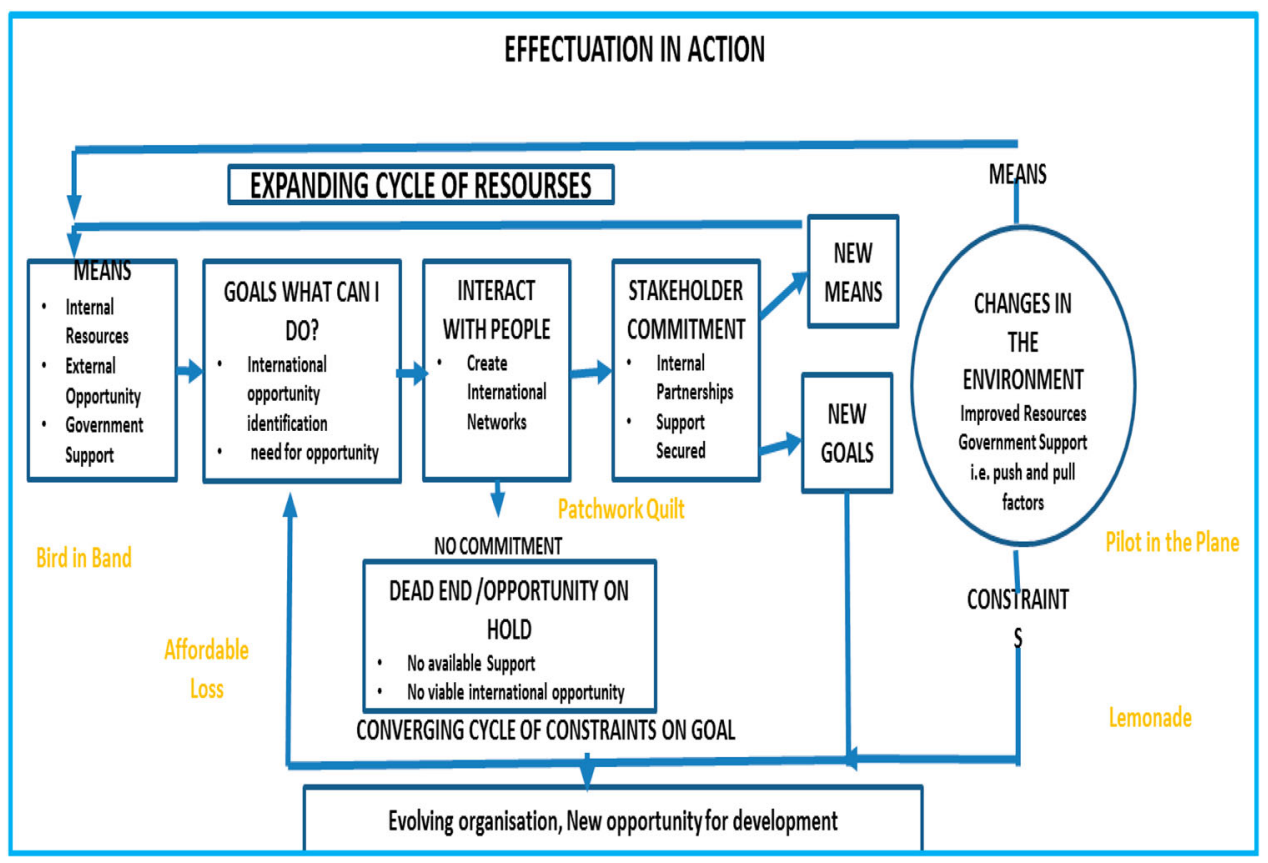

Figure 1. A conceptualization of effectual exporting. Source: Adapted by authors from Sarasvathy (2001, 2008).

success. All participants referenced this throughout the data suggesting that focusing on controllable opportunities is an important factor in the exporting process. Throughout this theme the references to nodes reflecting the principles of Effectuation would suggest that Effectuation is present in the exporting process and could be applied to cultivate exporting opportunities and growth.

\section{Conclusions}

This article contributes to entrepreneurship and business theory as it extends the context of Effectuation and examines it from an alternative perspective. Theme 1 explored how and why entrepreneurs begin exporting. The references throughout the data suggest that entrepreneurs apply a means-based approach when pursuing exporting opportunities. Theme 2 addressed government supports that entrepreneurs feel are needed from their 'grassroots' level perspective which acknowledged the importance of funding, but that mentoring was of greatest importance. This theme also highlighted that entrepreneurial selling is a different technique to business selling for a known brand. This suggests that successful entrepreneurs could in fact be used to gain knowledge on 'the entrepreneurial selling processes' and teach this technique which addresses the need for more experienced entrepreneurs in international selling (National Policy Statement on Entrepreneurship in Ireland, 2014). Theme 3 explored the concept of Effectuation and it was evident from the interviewees that effectual logic was used in selecting opportunities and in making decisions that helped make their ventures successful. It is widely acknowledged in the exporting literature that exporting increases productivity and survival rates (Albornoz 
et al., 2012; Greenaway et al., 2007; Greenaway \& Kneller, 2007; Klein et al., 2013; Putniņš, 2013; Van Biesebroeck, 2005).

The themes presented in this article suggest that Effectuation is present in the exporting process and could be applied to improve this process as suggest by Sarasvathy $(2001,2008)$ and Galkina (2013). The conceptual framework presented in Figure 1 illustrates how the Effectual Cycle can be adapted for the entrepreneurial exporting journey. The principles of Effectuation (Sarasvathy, 2001) have also been included in this model to illustrate how they occur in the entrepreneurial exporting journey. Figure 1 illustrates an overview of Effectual Exporting by highlighting how the Effectual Cycle can be adapted to the entrepreneurial exporting journey. This suggests that Effectuation could be applied to improve the exporting process and provide an alternative approach to exporting.

While the findings presented in this paper suggest potential for Effectual Exporting, further study in this area is recommended and testing of larger sample of the population is required to further validate if effectual logic is present and to what extent. Further study would determine the potential of effectual logic and its transferability as a teachable skill. The researcher also recommends further study to apply Effectuation to struggling firms to engage in exporting activity to revive their business. If a firm is to apply a means-based effectual approach to select international markets this could present the opportunity to revive their firm. From a practical perspective this research suggests that entrepreneurs engaged in exporting or seeking to export could benefit from mentoring from experienced international sales executives who could leverage their knowledge of international markets, sales and entrepreneurial processes.

\section{Disclosure statement}

No potential conflict of interest was reported by the authors.

\section{References}

Action Plan for Jobs. (2015). Action plan for jobs. Dublin: Department of Jobs, Enterprise \& Innovation.

Aikins, S. K. (2009). Political economy of government intervention in the free market System. Administrative Theory \& Praxis, 31, 403-408.

Albornoz, F., Calvo Pardo, H. F., Corcos, G., \& Ornelas, E. (2012). Sequential exporting. Journal of International Economics, 88, 17-31.

Anderson, J. E., \& Wincoop, E. v. (2004). Trade costs. Journal of Economic Literature, 42, 691-751.

Andersson, S. (2011). International entrepreneurship, born globals and the theory of effectuation. Journal of Small Business and Enterprise Development, 18(3), 627-643.

Bobera, D., Lekovic, B., \& Berber, N. (2014). Comparative analysis of entrepreneurship barriers: Findings from Serbia and Montenegro. Inzinerine Ekonomika-Engineering Economics, 25(2), $167-176$.

Braun, V., \& Clarke, V. (2006). Using thematic analysis in psychology. Qualitative Research in Psychology, 3, 77-101.

Brettel, M., Mauer, R., Engelen, A., \& Küpper, D. (2012). Malte Brettel René Mauer René Mauer Andreas Engelen Andreas Engelen Daniel Küpper Daniel Küpper. Corporate effectuation: Entrepreneurial action and its impact on $\mathrm{R} \& \mathrm{D}$ project performance. Journal of Business Venturing, 27, 167-184.

Carland, J. W., Hoy, F., \& Carland, J. A. (1988). "Who is an entrepreneur?" Is a question worth asking. American Journal of Small Business, 12, 33-39. 
Casson, M., \& Wadeson, N. (2007). Entrepreneurship and macroeconomic performance. Strategic Entrepreneurship Journal, 1, 239-262.

Castaño, M.-S., Méndez, M.-T., \& Galindo, M-Á. (2015). The effect of social, cultural, and economic factors on entrepreneurship. Journal of Business Research, 68, 1496-1500.

Central Bank of Ireland. (2015). Central bank publications. Retrieved from Centralbank.ie: https:// www.centralbank.ie/Pages/SearchResults.aspx?k=exporting\%202015

Chesbrough, H. (2010). Business model innovation: Opportunities and barriers. Long Range Planning, 43, 354-363.

Chiles, T. H., Bluedorn, A. C., \& Gupta, V. K. (2007). Beyond creative destruction and entrepreneurial discovery: A radical Austrian approach to entrepreneurship. Organization Studies, 28, 467-493.

Crespi, G., Criscuolo, C., \& Haskel, J. (2008). Productivity, exporting, and the learning-by-exporting hypothesis: Direct evidence from UK firms. Canadian Journal of Economics, 41, 619-638.

Crick, D., \& Crick, J. (2016). The first export order: A marketing innovation revisited. Journal of Strategic Marketing, 24(2), 77-89.

CSO. (2016). Trade by enterprise characteristics 2016. [Online]. Retrieved April 16, 2019, from https://www.cso.ie/en/releasesandpublications/ep/p-tec/tec2016/ees/

CSO. (2019). Goods exports and imports. [Online]. Retrieved April 16, 2019, from https://www.cso. ie/en/releasesandpublications/er/gei/goodsexportsandimportsfebruary2019/

Delmar, F., \& Davidsson, P. (2000). Where do they come from? Prevalence and characteristics of nascent entrepreneurs. Entrepreneurship and Regional Development, 12, 1-23.

Department of Enterprise, Trade \& Innovation. (2015). A strategy and action plan. Dublin: Department of Enterprise, Trade \& Innovation.

European Commission. (2019, May 10). Accessing marketing. Retrieved from Europa.eu: http://ec. europa.eu/trade/policy/accessing-markets/goods-and-services/

Evers, N., \& O'Gorman, C. (2011). Improvised internationalization in new ventures: The role of prior knowledge and networks. Entrepreneurship and Regional Development, 23, 549-574.

Freund, C., \& Pierola, M. D. (2001). Export entrepreneurs. Geneva: The World Bank.

Galkina, T. (2013). Entrepreneurial networking: Intended \& unintended processes. Hanken School of Economics, Department of Management \& Organisation.

Grandinetti, R., \& Mason, M. (2012). Internationalization modes other than exporting. European Business Review, 24, 236-254.

Greenaway, D., Guariglia, A., \& Kneller, R. (2007). Financial factors and exporting decisions. Journal of International Economics, 73, 377-395.

Greenaway, D., \& Kneller, R. (2007). Exporting productivity \& agglomeration. European Economic Review, 73(2), 919-939.

Irish Exporters Association. (2014). AIB outlook exports. Dublin: AIB.

Johanson, J., \& Wiedersheim-Paul, F. (1975). The internationalization of the firm? Four Swedish cases. Journal of Management Studies, 12, 305-323.

Kim, W. C., \& Mauborgne, R. (2005). Blue ocean strategy: From theory to practice. California Management Review, 47(3), 105-126.

Klein, M., Moser, D., \& Urban, D. (2013). Exporting, skills and wage inequality. Labour Economics, 25, 76-85.

Kraaijenbrink, J., Spender, J.-C., \& Groen, A. J. (2010). The resource-based view: A review and assessment of its critiques. Journal of Management, 36(1), 349-372. doi:10.1177/ 0149206309350775

Mauer, R., Smit, W., Forster, W., \& York, J. (2010). Curry in a Hurry? New firm creation acceleration by nascant entrepreneur usage of effectuation. Working paper.

National Policy Statement on Entrepreneurship in Ireland. (2014). National policy statement on entrepreneurship in Ireland. Dublin: Department of Jobs, Enterprise and Innovation.

Nguyen, D. (2012). Demand uncertainty: Exporting delays and exporting failures. Journal of International Economics, 86, 336-344.

Perry, J., Chandler, G., \& Markova, G. (2011). Entrepreneurial effectuation: A review and suggestions for future research. Entrepreneurship Theory and Practice, 36(4), 837-861. doi:10.1111/j. 1540-6520.2010.00435.x 
Putniņš, T. J. (2013). Exporting by Latvian companies: Vitality, drivers of success, and challenges. Baltic Journal of Economics, 41:1, 3-33.

Quest, G., McQueen, K., \& Namey, E. (2012). Applied thematic analysis. Washington, DC: Sage.

Rasheed, H. S. (2005). Foreign entry mode and performance: The moderating effects of environment. Journal of Small Business Management, 43, 41-54.

Read, S., Song, M., \& Smit, W. (2009). A meta-analytic review of effectuation and venture performance. Journal of Business Venturing, 24, 573-587.

Renko, M. (2012). Early challenges of nascent social entrepreneurs. Entrepreneurship: Theory \& Practice, 37(5), 1042-2587. doi:10.1111/j.1540-6520.2012.00522.x

Reymen, I., Berends, H., Oudehand, R., \& Stultiens, R. (2016). Decision making for business model development: A process study of effectuation and causation in new technology based ventures. $R$ \& D Management, 47.

Sarasvathy, S. (2001). Causation and effectuation: Toward a theoretical shift from economic inevitability to entrepreneurial contingency. Academy of Management Review, 26, 243-263.

Sarasvathy, S. (2012). Effectuation 101. Retrieved from Effectuation.org: http://www.effectuation. org/learn/effectuation-101

Sarasvathy, S. D. (2008). Effectuation: Elements of entrepreneurial expertise. New Horizons in Entrepreneurship. Northampton, MA: Edward Elgar Publishing.

Sarasvathy, S., Kumar, K., York, J. G., \& Bhagavatula, S. (2013). An effectual approach to international entrepreneurship: Overlaps, challenges and provocative possibilities. The Journal of Entrepreneurship Theory and Practice, 38(1), 71-95.

Saunders, M., Lewis, P., \& Thornhill, A. (2012). Research methods for business students. Essex: Pearson.

Sekaran, U., \& Bougie, R. (2010). Research methods for business a skill building approach. West Sussex: Wiley.

Shane, S., \& Venkataraman, S. (2000). The promise of entrepreneurship as a field of research. Academy of Management Review, 22(2), 217-226.

Steup, M. (2014). Epistemology. Retrieved from The Stanford Encyclopaedia of Philosophy: http:// plato.stanford.edu/archives/spr2014/entries/epistemology/

Van Biesebroeck, J. V. (2005). Exporting raises productivity in sub-Saharan African manufacturing firms. Journal of International Economics, 67, 373-391.

$\mathrm{Wu}, \mathrm{L}$., \& Li, J. (2011). Perceived value of entrepreneurship: A study of the cognitive process of entrepreneurial career decision. Journal of Chinese Entrepreneurship, 3, 134-146.

Yin, R. K. (2009). Case study research: Design and methods (4th ed.). Thousand Oaks, CA: Sage.

Young, J. C., Butler, J. R., Jordan, A., \& Watt, A. D. (2012). Less government intervention in biodiversity management: Risks and opportunities. Biodiversity and Conservation, 21, 1095-1100. 